THE WONDERS OF A BIRD'S BILL* By B. S. Bowisish.

Probarly few people ever stopped to think what a woiderful organ a bird's bill really is, less as to struc ture than to what is accompllshed with it. It has been asked what a man would do if he had to build his structs and cleans its nest, dresses its feathers and cares for the cleanliness of its young, and in some cases, as the parrots, assists itself in climbing. As a mouth the bill tears, cuts, or crushes the food, accord ing to what it consists of. The bill is both lip and

The general shape of the bill is such as to give the little deviation from one general pattern of bill. The difference in the nature of the food, however, and in the manner of procuring it, among the different orders and families of birds, is such that there is probably no other one feature common to the members of any group, in which is to be found so much diversity in

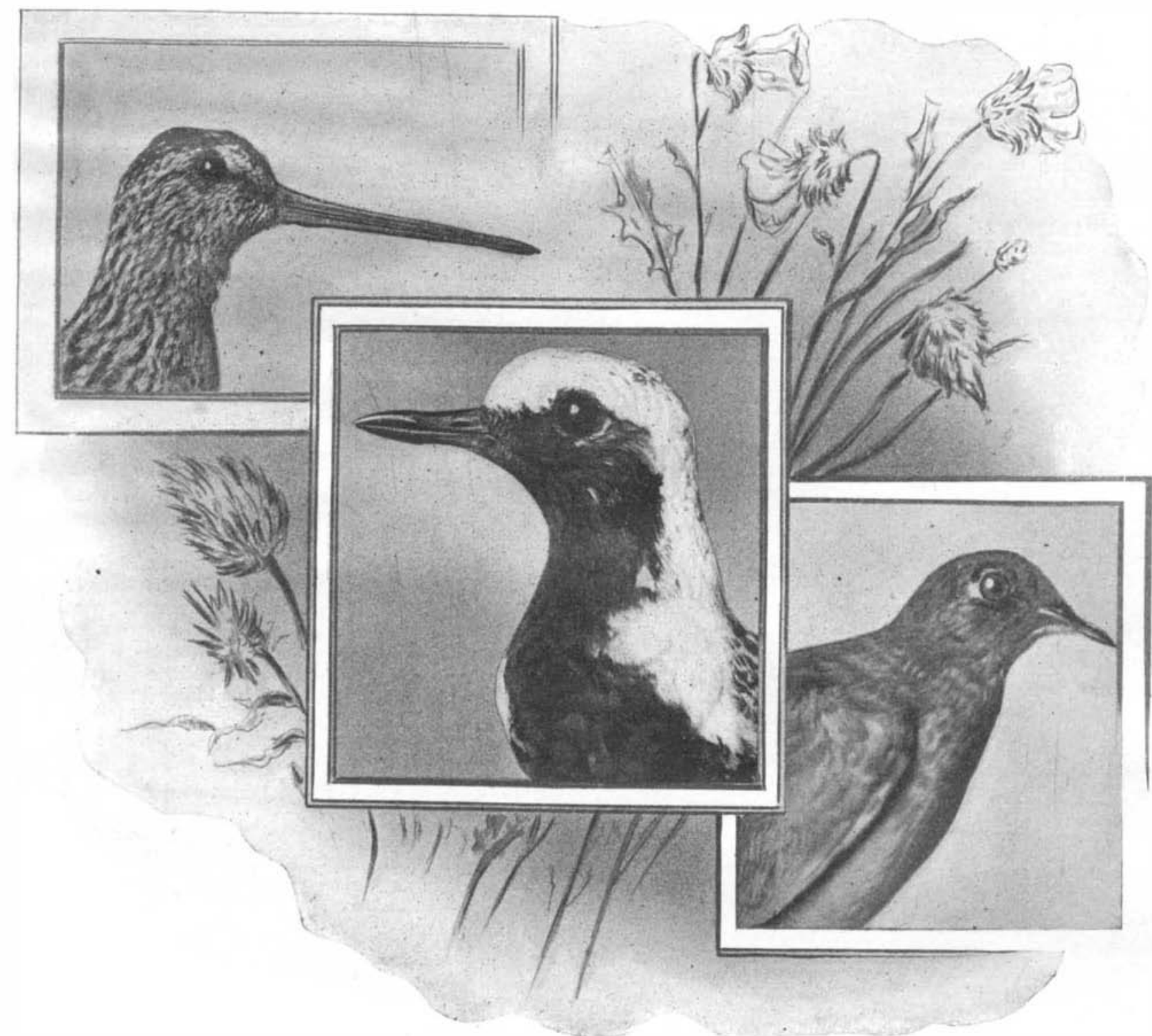

DOWITCHER.

home and procure his food with his hands tied behind him. This is in effect what the bird has to do, and the constructive and artistic work shown in nest-building has ever

bird's bill is hand and mouth. As a hand it takes, holds, and corries food and nesting material, con- From Americau Homes and Gardens, Publisbed by Monn Co
BLACK-BELLIED PLOVER.

greatest strength with the utmost lightness and delicacy. It is formed of light, projecting skull bones, skin.

The primary fur The primary functions of a bird's bill are, first, the securing of food, and secondly, the bullding of the might be supposed that there would be comparatively
MOURNING DOVE.

For the most part the form of the bill is found to correspond pretty closely with the nature of the food and the manner of procuring it.

The various requirements of nest building and minor matters seem to be made subservient to this essential one. Taking as a type form of bill, the shape common to birds which are omnivorous in food habits, we have a nearly straight conical bill, of moderate proportions,

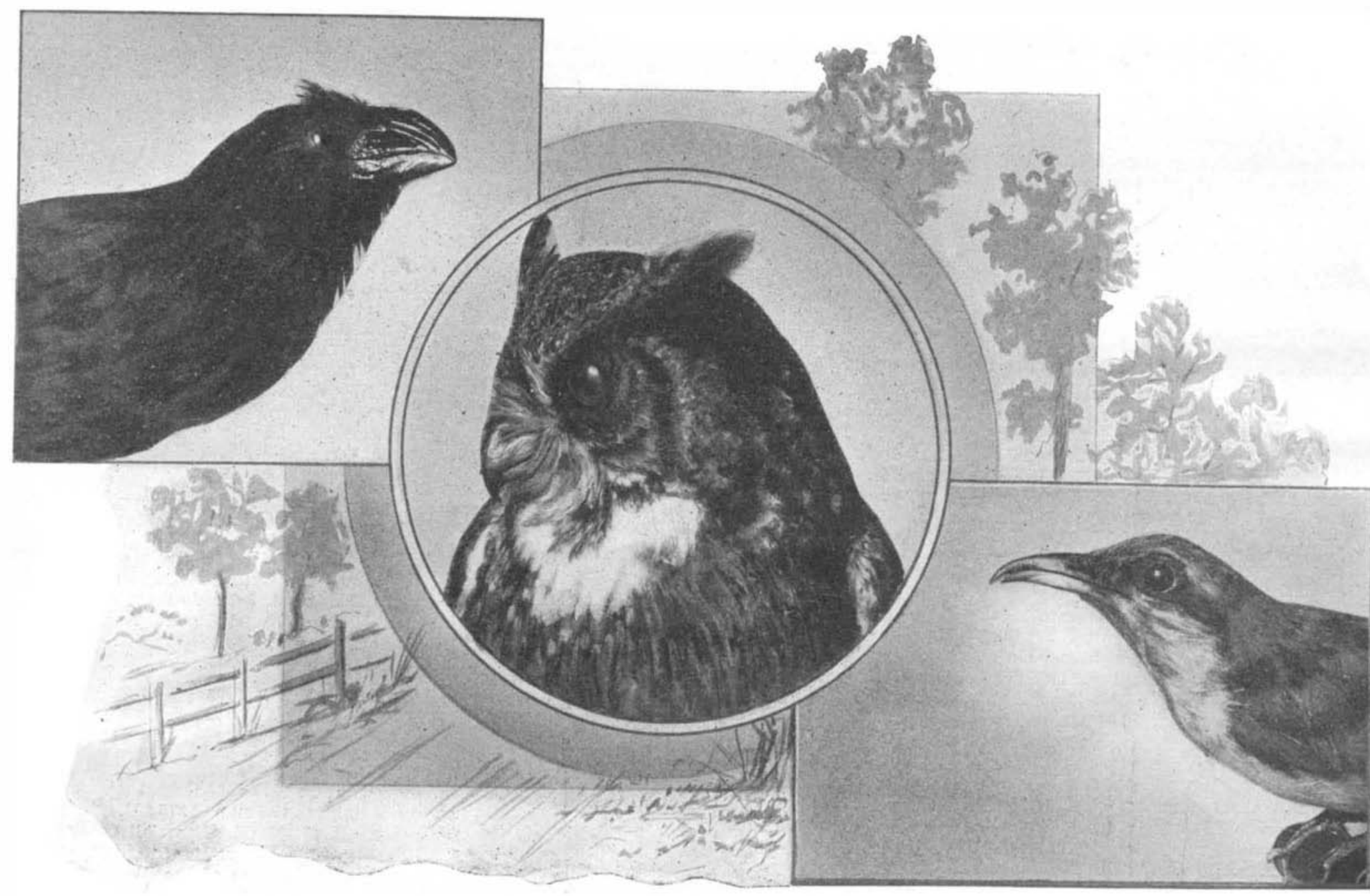


of which the crow's is a fair example. Such a bill while not as well adapted to the procuring of any on kind of food as some specialized form, yet seems best adapted to meet the needs of obtaining a varied bill of fare under diverse conditions. In many cases the general nature of the food of two or more families is alike, but the method of procuring it varies greatly among the different orders of birds, a fact which re sults in considerable difference in size and shape of bill.

The food of both pelican and man-o'-war bird is fish. The former is an honest fisherman, and, like other honest fishermen, has times of abundant success, an others when he has only "fisherman's luck." It is therefore to his advantage to have a bill adapted for the rapid gobbling up of the small fish of the schools with which he may come in contact, as well as a basket in which they may be deposited until a time of leisure for devouring them presents itself. Strength is not an essential, hence we find the bill of the pelican attaining a length of ten or more inches, the upper mandible only of sufficient strength to meet the requirements, the lower mandible a light, pliable framework, divided nearly to the tip, and supporting a capacious pouch.

The man-o'war bird, besides being sometimes an honest fisherman, is often a robber of other fishermen, worrying other birds who have made a catch until the prey is dropped, to be seized by the marine highwayman. While the bill is of the same general pattern as that of the pelican, it is modified to meet the difference in habit, lightened and made less cumbersome by being much shortened (4\% inches), and decidedly firmer, with a greatly reduced pouch.

The puffins, another family of seabirds, include crus tacea with fish in their bill of fare, and find a most radically different form of bill best adapted to their needs. The gulls and terns, birds of the seas and great lakes, are more omnivorous in their food habits, being water scavengers, and their bills approach much more nearly" the type selected. Seabirds either build no nest at all, laying their eggs on bare rock or sand, or construct a loose, shabby afrair, of seaweed, so that they are unhampered in this task by the lack of more delicate organ.

The flamingo, feeding in more or less shallow lagoons, on certain crustacea, is compelled, by his height to take his food with bill inverted-that is, the lowe mandible is above while feeding as the bird's neck is bent down. Often scraping the food from the bottom of the pools, an exceedingly peculiar shape of bill is the result of the bird's special needs.

The typical shape of bill in the duck family is famillar to every one from the bill of the domesticate bird. It varies in degree to a considerable extent in the different forms, but the general shape remains The spoonbill has a very well shaped ladle for scooping The roul

ing example of erfect adaptation to special requirements. Long, slen.

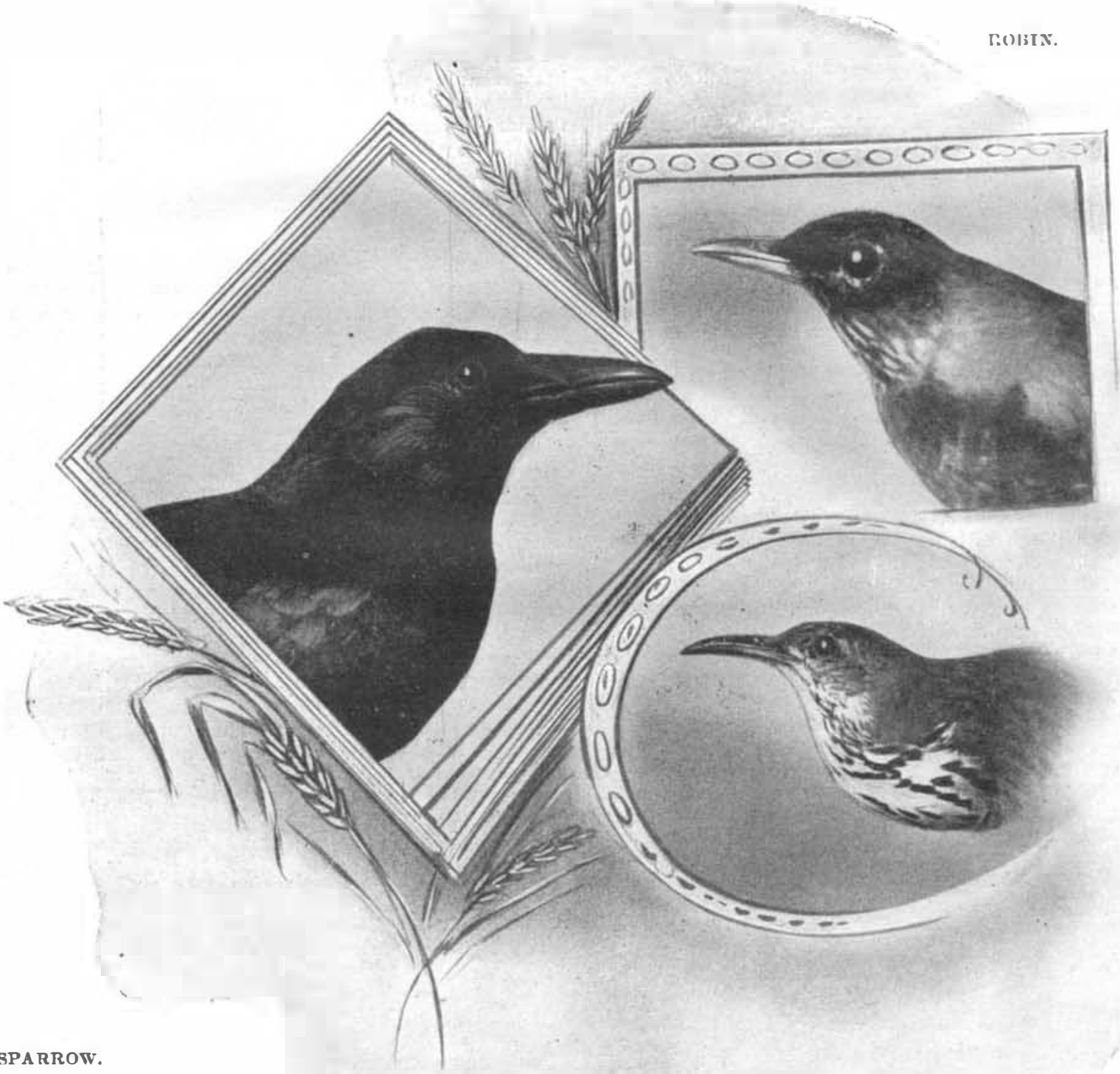

RIII-FYRD VIREO.

SONG SPARRON.

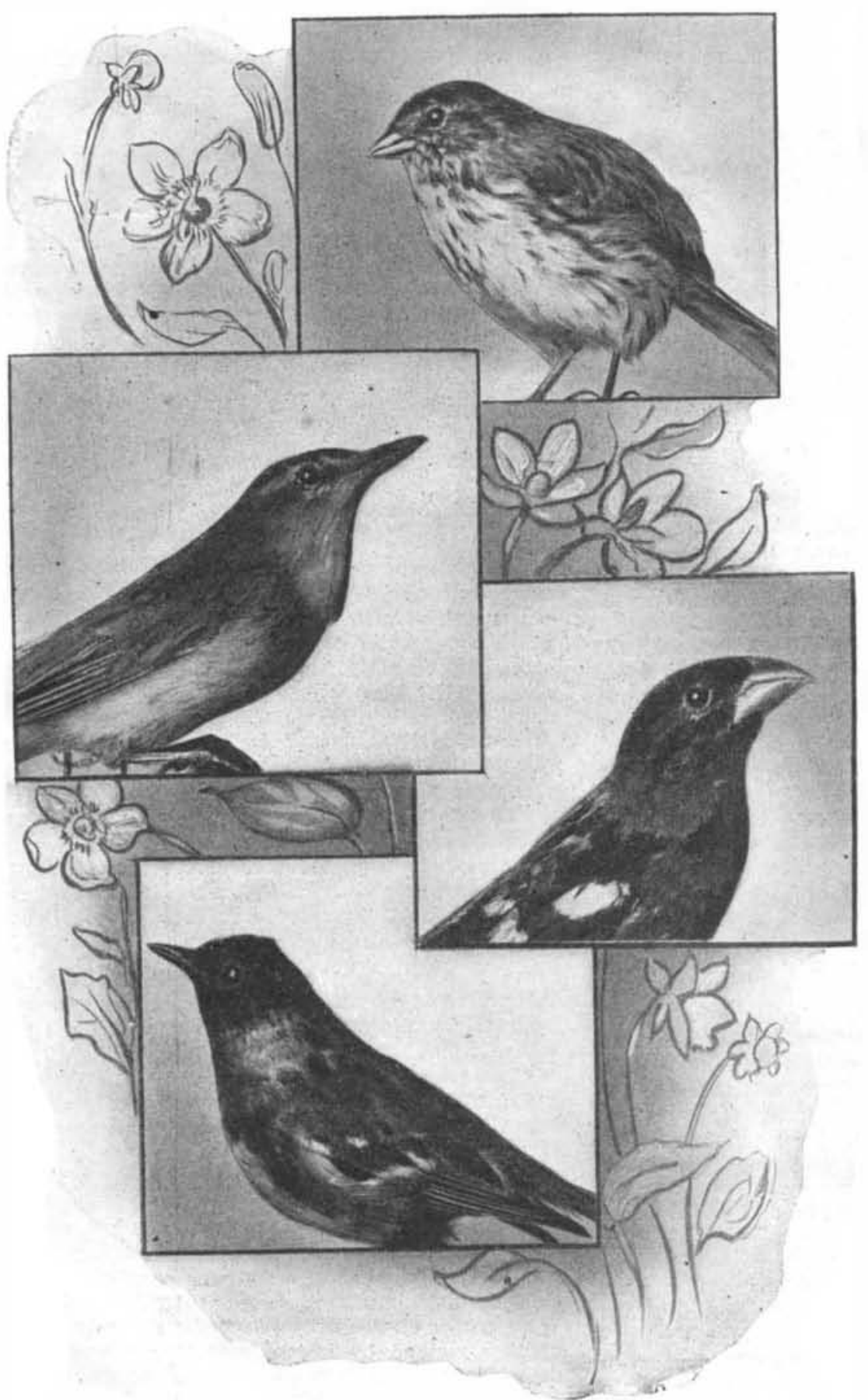

cleow.

LUNG-BILLKL THIRASHEH

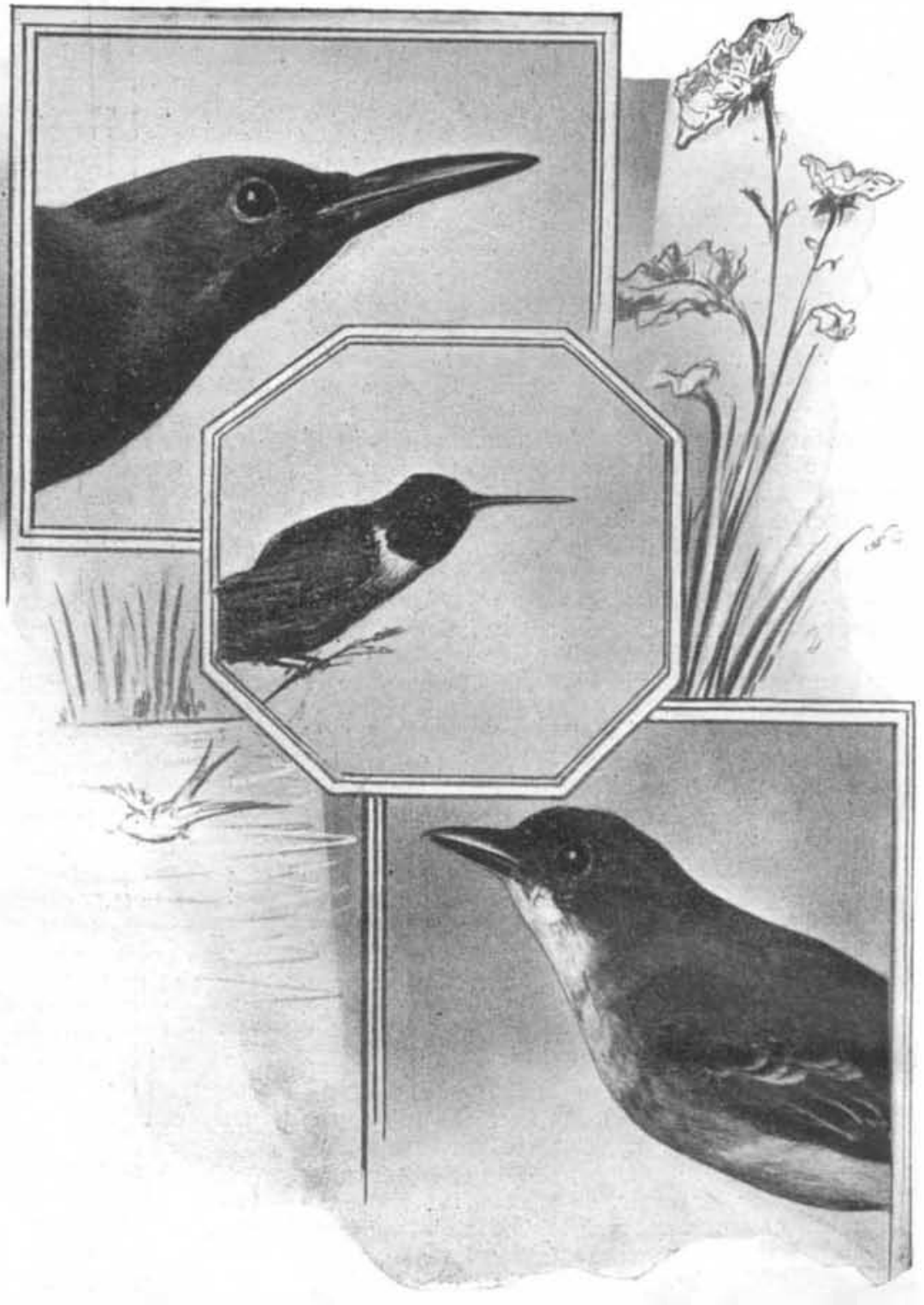


der, and tubular in shape, the upper mandible projects beyond the lower, and the tip is flexible, and exceed ingly sensitive. The bird feeds by probing in soft,
damp earth for worms and the like, the flexible mandidamp earth for worms and the like, the flexible mandible tip acting as a sensitive finger to locate and extract
the prey. The snipe, with a bill almost exactly simi the prey. The snipe, with a bill almost exactly simi
lar, has about the same haibits in feeding. The sand pipers, with food habits more intermediary betwee the woodcock's and those of birds possessing the type form, have bills more approaching in shape those of the latter, and the plovers still more typically shaped beaks.

There are examples of very remarkable bills, whose strange shapes are not explained by requirements of food-getting or nest-building. These are most con picuous among certain foreign species. The rhinoceros hornbill of Africa is an example of one of these very peculiar forms of bill. In such cases it is suppose
that the decorations of the bill serve as sexual attrac-

The gallinaceous birds, to which our domestic fow belongs, are more or less omnivorous in feeding, an the bill forms are not widely divergent from the type. The hawks and owls require bills that will hold and tear prey, and they have prolonged and strongly curved upper mandibles and bills of great strength. The shrike, belonging to a very different order, yet with food habits much the same, has a similar shape of bill. The kingfisher, securing his prey with a scissors-like motion of the bill, after a dive, has a large and powerful beak, well suited to cut the water as he plunges. A small relative, found only in the West Indies, the tody, feeds upon small insects, taken both on the wing and from the foliage, and the bill is wide and long, to better adlapt it to the ready secur-
ing of its prey. Both of these birds excavate holes in ing of its prey. Both of these birds excavate holes in
banks of earth for nesting, for which work their bills

form excellent spades. eating habits, but is also a very useful member in

southern sparrows, the seed-eating type of bill finds its most extreme proportions. The warblers are amon the birds exhibiting the other extreme, with the
thrashers, wrens, and creepers, as examples of the dethrashers, wrens, an
curved form of bill.

curved form of bill.
One remarkable example of the surprising manner One remarkable example of the surprising manner
in which nature secures for her creatures that strucin which nature secures for her creatures that strucof the crossbill. One unfamiliar with the bird's method of feeding would suppose that it would be fatally hampered in eating by the crossed mandibles, but after having watched the dexterity and rapidity with which the bird extracts the seeds from cones (its principal
food), one will readily agree that the bill is shaped to

food), one
its needs.

The growth of the bills of birds continues through life as with our finger nails. Where freak or accident prevents the proper meeting of the mandibles, the rebill minimizes the wear to a point where it is exceeded by the growth, resulting, sometimes, in peculiar malformations. Such a case was exhibited by a Porto
Rican woodpecker which I collected. It had suffered an injury to the lower mandible near the base. Apparently, as this injury healed, the edges of the wound contracted, warping the mandible to that side, and tending to a corkscrew-shaped growth. The bird was debarred from hammering by the weak, misshapen bill, and the growth which normally would have re-
placed wear abnormally prolonged both mandibles, though why the lower so much more than the upper is not easy to understand. In this bird the upper
mandible had exceeded the average length by about a mandible had exceeded the average length by about a
third of an inch, while the lower mandible was nearly third of an inch, while the lower mandible was nearly
three times the normal length. The lower mandible three times the normal length. The lower mandible made a half turn, so that what should have been its lower surface, was, at the tip, the upper. It would
have been interesting to know if this bird was able have been interesting to know if this bird was able
to feed on seeds and fruit, which normally form large part of the food of this species, or whether it

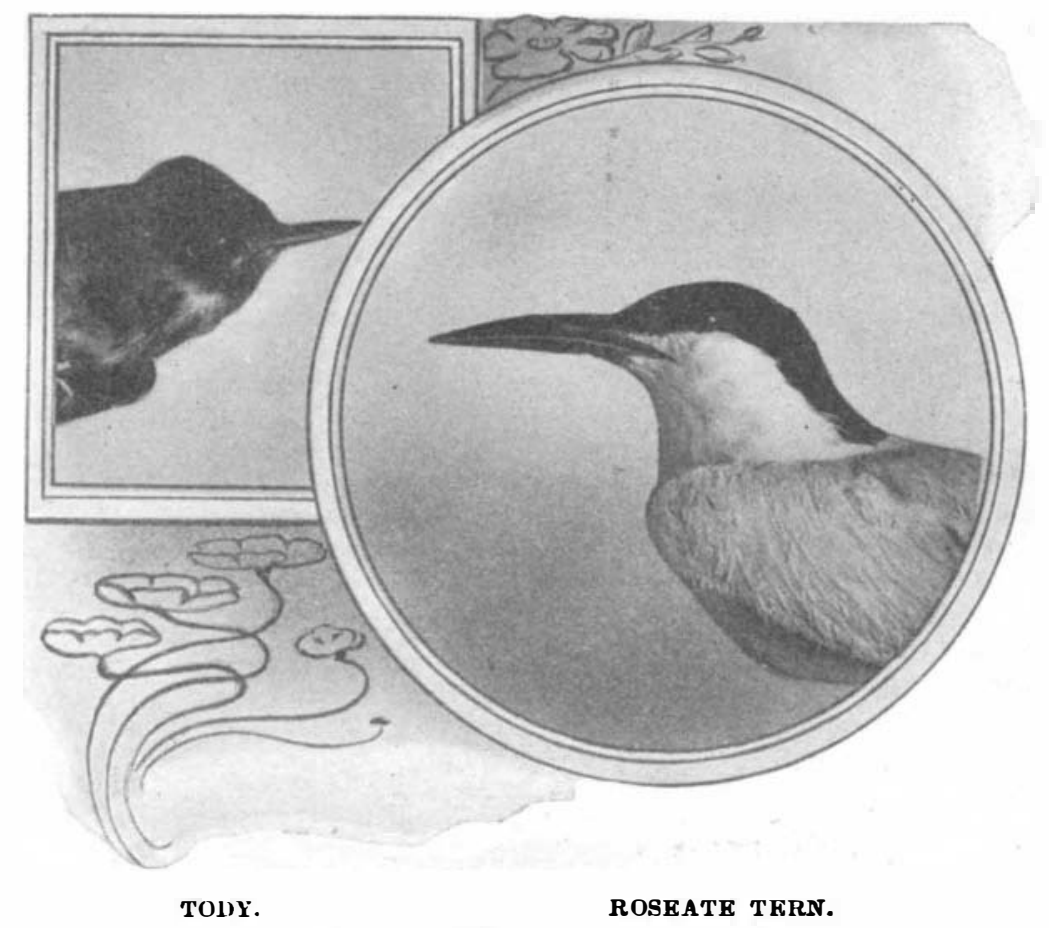

THE WONDERS OF A BIRD'S BILL.

climbing. It is very heavy and strong, with the upper mandible well curved. The tongue of the parrot is also remarkable among bird tongues for the resemblance it bears to the human tongue. This probably accounts for the facility with which these birds learn to articulate words. The food of humming-birds consists of two quite different substances, the nectar of flowers and minute insects. Even the latter are taken chiefly from the interior of flowers, and to facilitate the obtaining of this food the birds are equipped with bills taking the form of long, slender tubes, and with tongues of unusual and very interesting structure.

In the tyrant flycatchers, comprising the kingbird, crested flycatcher, least flycatcher, woodpewee, and others, a rather typically formed bill is considerably widened, tending to render more easy the capturing of insects on the wing. The typical woodpecker bill is a very efficient chisel, accompanied by a tongue which acts as a probe. This structure finds its highest. per fection in the ivory-billed and pileated woodpeckers while the flicker, feeding much of the time in the manner of the meadow lark, and nesting usually only in the sof test of dead wood, has a bill shaped more like that of a meadow lark than that of other woodpeckers. Intermediate between these two forms come the downy and red-head, with many other species. A peculiar construction, permitting of the extreme protru-
sion of the tongue in woodpeckers, is the great length sion of the tongue in woodpeckers, is the great lengt from the base of the tongue around the back of the heal, on either side of the neck, over the top of the skull, with the ends resting close to the base of the upper mandible.

Among the smaller birds, as a rule, the more the Among the smaller birds, as a rule, the more the
food consists of seeds and vegetable matter the more food consists of seeds and vegetable matter the more
the bill tends to a heavy, short, conical shape, while those species feeling more exclusively on insects tend to have more slender, elongated, conical shaped bills, in some species more or less decurved. In the grosbeaks, some species of the tanagers, and some of the was fed by the mate, which was with it when shot. At the time it was collected the stomach was empty while that of the

As in the time of Noah the dove returned to the ark with an olive branch in its bill as a token of promise, so now, each spring, the birds return to our dooryards and shade trees, bearing nesting material, as though it were a sign of the delightful intercourse we may have, f we will but meet them in friendly spirit half way. The horny sheath of the bill is called rhampotheca and is formed by the outer layers of the malpygian cells. It resembles in structure the other horny parts, such as claws, nails, and spurs. In some birds, as some of the ducks, this covering remains soft except hawks and parrots the distal end of the upper man dible is hard; basal portion, called the cere, is thick and soft. This latter is usu

it the nostrils are inclosed. of parrots it is covered with feathers and in such cases its structure is similar to the ordinary skin.

The covering about the nostrils is soft in some species and presents a means of externally closing them though without special muscles. Such an arrangement is called an operculum, and is prominent in pigeons.

In petrels and shearwaters the operculum forms a
complete tube, whence these birds are called Tubinares or tube-nosed birds.

Grease for Wood Gearing.-The following compound is recommended for the lubrication of wooden-toothed wheels: Melt together at a moderate heat 30 parts by weight of tallow, 20 parts of palm oil, 10 parts of fish oil, and introduce while stirring, so as to obtain a perfectly homogeneous mixture, 20 parts of graphite washed and pulverized carefully.-Technische Rundschau. near the tip, which contains tactile organs. In the

In most species the cere is bare, but in some species
INSECTICIDES: THEIR PREPARATION AND USE.*

IN order to be able to apply insecticides intelligently and with success, it is important to understand something of the habits of the particular insects to be destroyed and also of the nature of the remetles to be used. Many insects, like grasshoppers and the potato beetle, devour the surface tissue of plants, while others, like plint-lice, squash-bugs, and scale insects, insert sharp tubular beaks into the tissues of plants af the firt class from beneath the surface. Insects means of food potsons, such as arsenic, Pars gren, means of food poisons, such as arsenic, Paris green, affected by food poisons and have to be killed by substances that come in contact with the surface of their bodies, or in come in contact with the surface of their to be a skilled entomologist in order to determine which class of insects is doing injury to the plants in question. If the leaves are ragged or eaten ful of holes, it is practically certain that the injury is being done by an insect with biting mouth parts. If
the leaves simply wilt and dry up without having the the leaves simply wilt and dry up without having the tissue eaten away, the insect doing the injury is of the second type mentioned. The most common remedies
for this class of insects are kerosene emulsion, whaleoil soap, crude petroleum, and lime salt and sulphur

In many cases it is impossible to get an insecticide upon the insect that it is desired to kill, or upon its food, and then other means have to be used to prevent the injuries. Borers, underground feeders upon roots,
and weevils living in seeds are examples of such
insects.

In the pages that follow I shall not attempt to treat of all the methods used to destroy insects or avoid their injuries, but the more important ones only.

SUBSTANCES TIIAT KIIL HY BHING EATEN.

Nearly all the food poisons have for their active principle arsenious acid, or white arsenic $\left(\mathrm{As}_{2} \mathrm{O}_{3}\right)$.
White hellebore and borax are about the only excep. White hellebore and borax are
tions.

While this is the cheapest of the arsenical poisons, it is used but little, except for the purpose of making arsenical compounds with other substances. Because some States have passed laws requiring a high per-
centage of arsenic in Paris green, arsenic has been centage of arsenic in Paris green, arsenic has been used as an adulterant of this poison, and thereby working an injury to the purchaser if not a benefit to
the manufacturer of it, because arsenic is much the manufacturer of it, because arsenic is much
cheaper than Paris green; and when it is mixed with cheaper than Paris green; and when it is mixed with
the latter, it greatly increases its liability to burn foliage. The reason that white arsenic burns foliage badly is that it dissolves in water and, when in solution, it penetrates the leaves and kills the living tissue.
Arsenical mixtures must never be in solution, but only in suspension, in the water that is used to distribute them upon foliage.

2. Arsenic Bran-Mash.

Prepared by mixing one pound of arsenic and 20 to 50 pounds of bran together with just water enough to thoroughly moisten the mass. Some prefer to add a pound of sugar to the above in order to cause the particles of bran to adhere to each other, so that it may
be distributed in little balls pressed together with the hands or with a paddle. This poisoned bran is used for the destruction of grasshoppers in orchards and vineyards where it is not possible to use a hopper-pan.
Many prefer to sow the moistened bran and arsenic Many prefer to sow the moistened bran and arsenic green may be substituted for the arsenic.

\section{Paris Green}

This poison in a pure state is said to be composed of three substances-arsenious acid, acetic acid, and
copper oxide-united in a chemical combination. The copper oxide-united in a chemical combination. The
percentage of arsenic may vary considerably, as these substances do not always combine in exactly the same proportions. The range is nearly always between 55 and 60 per cent arsenic, with an average of about 58 per cent. †Mr. J. K. Haywood, one of the chemists in the Department of Agriculture at Washington, D. C.,
says that the chemical composition of Paris green says. that
should be:
Arsenious acid...
Per cent.
Copper oxide
Acetic acid.
31.29

Pure Paris green is one of the very best of the arsenical compounds for the destruction of insects, but this poison is often found greatly adulterated upon the market. If adulteration is suspected, or if the poison is being purchased in any considerable quantity, it is advisable to test its purity in some way. Pure Paris green is entirely soluble in ammonia, giving a clear through the liquid, or settling to the bottom, the article is not pure. If the ammonia dissolves all, there can be little doubt that it is pure. This is a test that any one can make. The particles of Paris green are entirely bright green in color and globular in form, and the presence of an adulterant can be most easily detected under a microscope of moderate power. Prof. Woodworth of the University of California, explains another method by which impurities can usually be detected in Paris green. It is by placing a small

Abatract of a monogranh br C. P. Gillette. publiahed by the Agri-
cultural Experiment † Farmer's Bull. No. 146. U. S. Dcpt, of Agr, 